\author{
Ibrahim A. Abdelazim ${ }^{1}(D)$ A. Adilgereyeva ${ }^{2 *}(D)$, G. Zhurabekova ${ }^{3}(D)$ \\ ${ }^{1}$ Ain Shams University, Egypt, Cairo; Ahmadi hospital, Kuwait Oil Company (KOC), Kuwait, Ahmadi \\ ${ }^{2}$ West Kazakhstan Marat Ospanov Medical University, Kazakhstan, Aktobe \\ ${ }^{3}$ Al- Farabi Kazakh National University, Kazakhstan, Almaty \\ *e-mail: a.adilgereeva@mail.ru
}

\title{
STRUCTURE AND FUTURE PROSPECTIVE OF MATRIX METALLOPROTEINASES
}

\begin{abstract}
Matrix metalloproteinases (MMPs) are group of enzymes responsible for the collagen, and protein degradation in extracellular matrix (ECM). Collagen is the main structural component of connective tissue, and its degradation is an important process in the tissue development, remodeling, and repair. MMP family is divided into 6 groups: collagenases, gelatinases, stromelysins, matrilysins, membranetype MMPs, and non-classified MMPs. The MMPs, and MMP inhibitors (MMPI) have multiple biological functions in stages of cancer development. MMPs, and MMPI are extensively examined as potential anticancer medications. The need for selective and metabolically stable MMPs and MMP inhibitors determined the effect of their activity on biological systems. In particular, the relationship of MMPs with the immune system has revealed the potential for the use of MMP inhibitors in therapy. As is known, the degree of invasive growth and metastasis of tumor cells are determined by their ability to cleave all ECM structures of the extracellular matrix - only MMPs can do this. It is important to note that ECM affects the behavior of both cancer cells and stromal, endothelial and immune cells in the environment. The fundamentally important role of ECM is dynamism during tissue homeostasis and the ability to regulate the activation of immune cells.
\end{abstract}

Key words: Structure, Prospective, Matrix Metalloproteinases, MMPs.

\author{
Ibrahim A. Abdelazim', А. Алимгереева2*, Г. Журабекова ${ }^{3}$ \\ ${ }^{1}$ Айн-Шамс университеті, Каир, Египет және Ахмади ауруханасы, \\ Кувейт мұнай компаниясы (КМК), Кувейт, Ахмади к. \\ 2Марат Оспанов атындағы Батыс Қазақстан медицина университеті, Қазақстан, Ақтөбе қ. \\ ${ }^{3}$ Әл-Фараби атындағы Қазақ, ұлттық университеті, Қазақстан, Алматы қ. \\ *e-mail: a.adilgereeva@mail.ru

\section{Матрицамық метаммопротеиназалардың құрымымы мен даму перспективалары}

Матрицалық металмопротеиназалар (ММП) - жасушадан тыс матрицада (ЖТМ) комлаген мен ақуыздың бөлінуіне жауапты ферменттер тобы. Коммаген дәнекер тінінің негізгі құрылымдық, құрамдас бөлігі болып табылады және оның деградациясы тіндердің дамуындағы, қайта қалыптасуы және қалпына келуіндегі маңызды процесс болып табылады. ММП түрлері 6 топқа бөлінеді: колмагеназдар, желатиназалар, стромелизиндер, матрилизиндер, мембраналық ММП және жіктеммеген ММП. ММП және ММП ингибиторлары (ММПИ) қатерлі ісік сатысында бірнеше биологиялық функцияға ие. ММП-лар және ММРИ потенциалды ісікке қарсы препараттар ретінде кеңінен зерттелуде. Селективті және метаболикалық тұрақты ММР және MМР ингибиторларының қажеттілігі олардың белсенділігінің биологиялық жүйелерге әсерін анықтады. Атап айтқанда, ММП иммундық жүйемен байланысы терапияда ММП ингибиторларын қолдану әлеуетін анықтады. Белгілі болғандай, ісік жасушаларының инвазиялық өсу дәрежесі және метастазы олардың жасушадан тыс матрицаның барлық ЭКМ құрылымдарын ылырау қабілетімен анықталады - мұны тек ММП ғана жасай алады. ЕСМ рак клеткаларының, сондай-ақ, қоршаған ортадағы стромальды, эндотелиальды және иммундық жасушалардың мінез-құлқына әсер ететіндігін атап өту маңызды. ЭКМ-нің маңызды рөлі - тіндік гомеостаз кезіндегі динамизм және иммундық жасушалардың активтенуін реттеу мүмкіндігі.

Түйін сөздер: құрылым, перспектива, матрицалық металмопротеиназалар, ММП. 


\author{
Ibrahim A. Abdelazim¹, А. ААилгереева2*, Г. Журабекова ${ }^{3}$ \\ 'Университет Айн-Шамс, Египет, г. Каир; Больница Ахмади, \\ Кувейтская нефтяная компания (КОК), Кувейт, г. АхмаАи \\ ²Западно-Казахстанский медицинский университет имени Марата Оспанова, Казахстан, г. Актобе \\ ${ }^{3}$ Казахский национальный университет им. а^ь-Фараби, Казахстан, г. Алматы \\ *e-mail: a.adilgereeva@mail.ru \\ Структура и перспективы \\ развития матриксных метам^опротеиназ
}

\begin{abstract}
Матриксные металмопротеиназы (ММП) - это группа ферментов, ответственных за расщепление комлагена и белка во внеклеточном матриксе (ЭКМ). Кол^аген яв^яется основным структурным компонентом соединительной ткани, и его деградация представляет важный процесс в развитии, ремоделировании и восстановлении тканей. Семейство ММП делится на 6 групп: колмагеназы, желатиназы, стромелизины, матрилизины, мембранные ММП и неклассифицированные ММП. ММП и ингибиторы ММП (ММПИ) имеют несколько биологических функций на стадиях развития рака. MMPs и MMPI широко изучаются как потенциальные противоопухолевые препараты. Необходимость селективных и метаболически стабильных ММП и ингибиторов ММП определили влияние их активности на биологические системы. В частности, взаимосвязь ММП с иммунной системой выявила потенциальные возможности применения ингибиторов ММП в терапии. Как известно, степень инвазивного роста и метастазирование опухолевых клеток определяются их способностью расщеплять все структуры ЭКМ экстраклеточного матрикса - это могут только ММП. Важно отметить, что ЕСМ влияет на поведение как раковых клеток, так и стромальных, эндотелиальных и иммунных клеток окружающей среды. Фундаментально важная роль ЕСМ - динамичность во время гомеостаза тканей и способность регулировать активацию иммунных клеток.
\end{abstract}

Ключевые слова: структура, перспектива, матриксные метамлопротеиназы, ММП.

\begin{abstract}
Abbreviations
MMPs - Matrix metalloproteinases; ECM - extracellular matrix; MMPI- Matrix metalloproteinases inhibitors; UVR - ultraviolet radiation; TNF - tumor necrosis factor; TGF -transforming growth factor; EGF - epidermal growth factor; PDGF - platelet-derived growth factor; FGF - fibroblast growth factor; VEGF - vascular endothelial growth factor; EMT - epithelial to mesenchymal transition.
\end{abstract}

\section{Introduction}

The main function of the extracellular matrix (ECM) is to maintain tissues mechanical, and biochemical specific properties. The tissue building cells are responsible for the synthesis of ECM components, and ECM has direct impact on the cell function [1].

Cell-matrix interactions occur due to the presence of specific receptors located on the matrix molecules, and on the surface of binding cell. The receptors play a dominant role in cells connection, migration, regulation of the cell's differentiation, and proteins expression. Pericellular matrix creates a physiological micro-environment for the cell protection against harmful, physical factors, and facilitates the transmission of signals [2]. Collagen is the main structural component of connective tissue; it maintains the organs stability and support their structural integrity. The collagen, and collagen-degrading enzymes family are characterized by a repeated tripeptide domain rich in proline, which is necessary to form a triplet-helix of collagen. This group of proteins is responsible for ECM formation [3]. The molecular structure, and metabolism of various collagen in tissues is important to understand the process of the embryo development, and pathogenesis human diseases. In addition, the expression and function of various types of collagen allow better understanding diseases that result from the molecular defects in the gene encoding different collagen structure (including osteogenesis imperfecta, Alport, and Ehlers-Danlos syndrome, and epidermolysis bullosa). The disorders of collagen metabolism occurs in osteoarthritis, osteoporosis, and oncogenesis. The properties of different collagen, and enzymes that participate in collagen degradation is important for possible therapeutic use [4]

\section{Collagen degradation}

The degradation of collagen as one of ECM components is important process in the development of diseases such as cancer, rheumatoid arthritis, nephritis, chronic ulcers, and fibrosis. The ECM degradation involves different types of proteases, and matrix metalloproteinase (MMPs) called matrixins 
are the major group of proteases [5]. They belong to group of endopeptidases, whose enzymatic activity is determined by $\mathrm{Ca}^{2+}$ and $\mathrm{Zn}^{2+}$ ions.

The first enzyme identified in this group was collagenase-1 (now referred to MMP-1), discovered by Gross and LaPiere in the tissue material from the tail of a tadpole of North American frog species [6]. Till now there are 24 known MMPs identified (23 in humans). Common classification distinguishes several MMPs, starting with MMP-1, and ending with MMP-28, but it does not include MMP-4, MMP-5, MMP-6, MMP-22. MMPs are involved in trophoblast implantation, embryogenesis, bone growth, angiogenesis, wound healing, and tissue regeneration. The expression of MMPs' genes is observed in the connective tissue, fibroblasts, neutrophils, monocytes, macrophages, and endothelial cells [7]. The biological activity of MMPs is regulated at the level of gene transcription, mRNA half-life modulation, regulation of secretion by cells, pro-enzymatic activation, inhibition of active enzymes, and enzyme activation.

MMPs are also subjected to neuro-immunohormonal control. The expression of MMPs is maintained in the tissues at a low level. Regulation of MMPs transcription at the cellular level is influenced by growth factors, cytokines, hormones, cell-cell interaction, and physical factors such as ultraviolet radiation (UVR). Factors that increase MMPs expression are inflammatory cytokines (interleukin-1, interleukin-6, tumor necrosis factor (TNF)), hormones and growth factors (transforming growth factor (TGF), epidermal growth factor (EGF), platelet-derived growth factor (PDGF), and fibroblast growth factor (FGF). The expression of MMP inhibitors (MMPI) influenced by corticosteroids, retinoic acid, heparin, and interleukin 4. MMPs are directly activated by proteases (plasmin, trypsin, and elastase), and certain metalloproteinases (MMP-1, MMP-2, MMP-8, MMP-9). Membrane-MMPs (MT-MMPs) are responsible for local activation of the inactive enzyme. In plasma, the largest part of the protease inhibitors are $\alpha 1$ antiprotease, and $\alpha 2$-macroglobulin. TIMPs may inhibit the active MMP and/or inhibit the activation of the pro-MMP into active MMP. The expression of TIMP is regulated by the growth factors, and cytokines [7].

\section{MMPs structure}

MMPs are ECM proteins, although some of them (MMP-1, MMP-2, and MMP-11) are found within cells, and their activity toward to the intracellular proteins has been confirmed as well.

MMP consists of several distinct domains. predomain, propeptide, catalytic, and hemopexin domains. Figure 1

Predomain absent in MT-MMPs. Propeptide domain, which usually consists of 80 AAs, contains highly conserved sequence PRCGVPDV. Catalytic domain consists of $170 \mathrm{AAs}$, and contains a threehistidine sequence, which is required for zinc chelation. A typical MMP contains a linker peptide (hinge region) of variable length, and hemopexin domain of 200 AAs, which is required for interactions with other MMPs, and TIMP [1]. MMP-7 (matrilysin-1), MMP-23, and MMP-26 (matrilysin-2) do not have hinge region and hemopexin domain.

MMP-23 has a unique cysteine-rich, and immunoglobulin domains. For MMPs activity, they require zinc ion in catalytic site, and proteolytical activation because they are secreted in an inactive form (pro-MMPs) [8].

\section{MMPs family}

On structure basis and substrate specificity, MMPs were divided into six groups including collagenases, gelatinases, stromelysins, matrilysins, membrane-type MMPs (MT-MMPs), and other non-classified MMPs [1]. Table 1 and Figure 2.

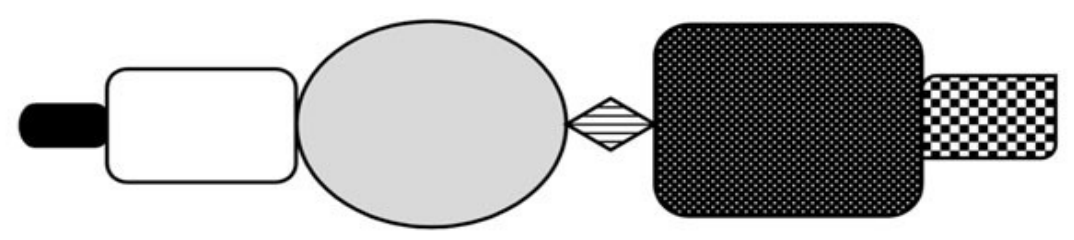

\begin{tabular}{|l|l|l|l|l|l|}
\hline Predomain & $\begin{array}{l}\text { Propeptide } \\
\text { domain }\end{array}$ & $\begin{array}{l}\text { Catalytic } \\
\text { domain }\end{array}$ & $\begin{array}{l}\text { Hinge } \\
\text { region }\end{array}$ & $\begin{array}{l}\text { Hemopexin } \\
\text { domain }\end{array}$ & $\begin{array}{l}\text { Transmembrane } \\
\text { domain }\end{array}$ \\
\hline
\end{tabular}

Figure 1 - Matrix Metalloproteinases structure 
Table 1 - Matrix Metalloproteinases (MMPs) family

\begin{tabular}{|c|c|c|}
\hline MMPs & $\begin{array}{l}\text { Numerical } \\
\text { classification }\end{array}$ & Biological effect \\
\hline Collagenase-1 & MMP-1 & $\begin{array}{l}\text { - } \quad \text { The migration of keratinocytes, re-epithelialization. } \\
\text { - } \quad \text { Cell migration, and proliferation. } \\
\text { - } \quad \text { Pratelet aggregation. } \\
\text { - } \quad \text { Cancer progression. } \\
\text { - } \quad \text { Proteolytic activity, degrade physical barriers. }\end{array}$ \\
\hline Collagenase- 2 & MMP-8 & $\begin{array}{l}\text { - } \quad \text { The activation of osteoclasts. } \\
\text { - } \quad \text { Anhancement of collagen affinity. } \\
\text { - } \quad \text { Cancer progression. } \\
\text { - } \quad \text { Cleavage of chemokines and regulation of their mobilization. }\end{array}$ \\
\hline Collagenase-3 & MMP-13 & - In cancer progression and induction and cell migration. \\
\hline Gelatinase A & MMP-2 & $\begin{array}{l}\text { - } \quad \text { Growth of axons, cell migration, and proliferation. } \\
\text { - } \quad \text { The differentiation of mesenchymal cell. } \\
\text { - } \quad \text { Neuronal apoptosis leading to neurodegeneration. } \\
\text { - } \quad \text { Cancer progression. } \\
\text { Cleavage of IGF binding proteins, proliferation. }\end{array}$ \\
\hline Gelatinase B & MMP-9 & $\begin{array}{l}\text { - } \quad \text { Collagen affinity enhancing, and tumor cell resistance. } \\
\text { - } \quad \text { Pro-inflammatory and anti-inflammatory activity. } \\
\text { - } \quad \text { Cancer progression. } \\
\text { - }\end{array}$ \\
\hline Stomelysin-1 & MMP-3 & $\begin{array}{l}\text { Migration of cells, and epithelial cells apoptosis. } \\
\text { - } \quad \text { Anithelial-mesenchymal conversion. } \\
\text { - } \quad \text { In cancer protiferation, proments and anti- inflammatory activity. } \\
\text { Upregulation of angiogenesis. }\end{array}$ \\
\hline Stomelysin-2 & MMP-10 & $\begin{array}{l}\text { - } \quad \text { In cancer progression } \\
\text { - } \quad \text { Degradation of collagen. } \\
\text { Generation of endostatin, and angiostatin. }\end{array}$ \\
\hline Stomelysin-3 & MMP-11 & $\begin{array}{l}\text { In cancer progression. } \\
\text { - } \quad \text { Release of } \alpha 1 \text {-proteinase inhibitor. } \\
\text { - }\end{array}$ \\
\hline Matrilysin-1 & MMP-7 & $\begin{array}{l}\text { - } \quad \text { Adipocyte differentiation. } \\
\text { - } \quad \text { Increagen affinity enhancement. } \\
\text { - } \quad \text { Cell differentiation, and abnormal cell aggregation. } \\
\text { - } \quad \text { Increase cells invasiveness. } \\
\text { - } \quad \text { Pro-inflammatory activation of osteoclasts. } \\
\end{array}$ \\
\hline Metalloelastase & MMP-12 & \\
\hline Matrilysin-2 & MMP-26 & \\
\hline MT-MMP & MMP-14 & $\begin{array}{ll} & \text { Anti-inflammatory } \\
\text { - } & \text { Epithelial cell migration, and adhesion reduction. } \\
& \text { Trailers embryo to the uterine epithelium. }\end{array}$ \\
\hline MT-MMP 2 & MMP-15 & - $\quad$ Adhesion and cell flattering reduction \\
\hline MT-MMP 3 & MMP-16 & - $\quad$ Adhesion and cell flattering reduction \\
\hline MT-MMP 4 & MMP-17 & \\
\hline MT-MMP 5 & MMP-24 & \\
\hline
\end{tabular}




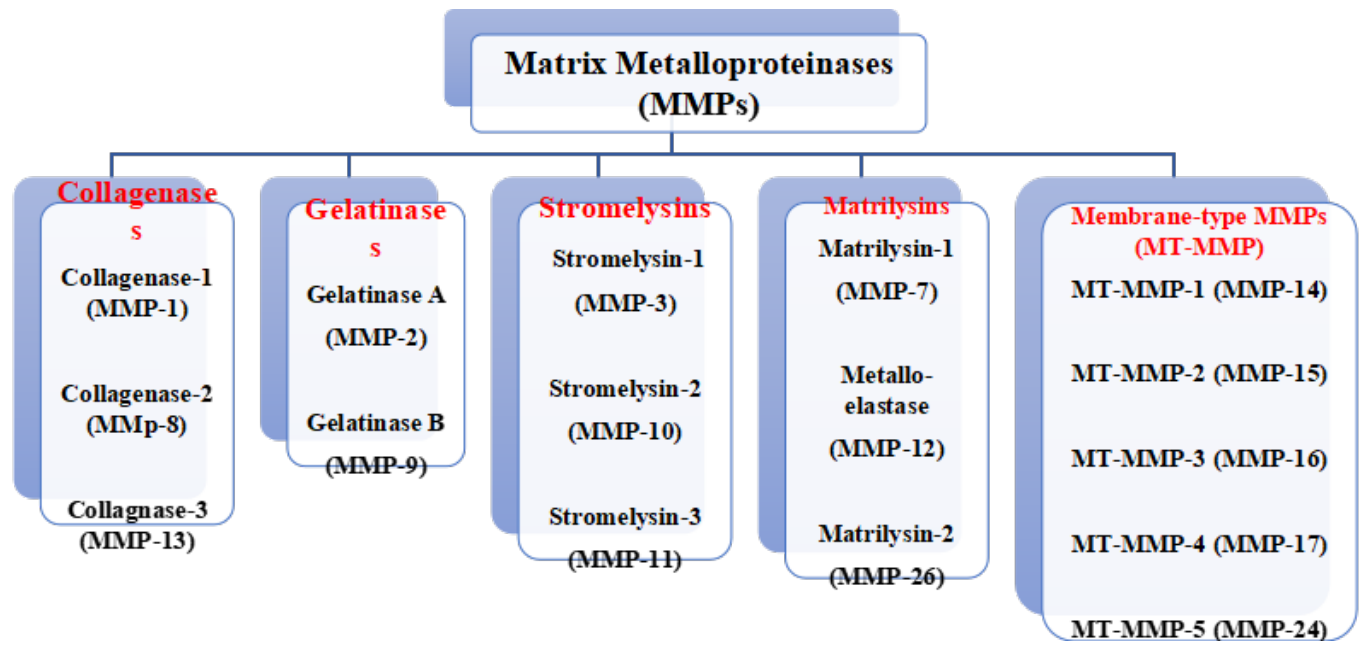

Figure 2 - Matrix Metalloproteinases (MMPs) family

\section{MMPs and cancer}

Interactions of the cells with ECM are important for pathological changes occurring during cell transformation, and carcinogenesis. Some ECM proteins affect the tumor through their effect on cell migration or angiogenesis. MMPs were associated with metastasis facilitation by breakdown of ECM physical barriers. However, now it is confirmed that they have multiple biological functions in all stages of cancer, from initiation to outgrowth of clinical metastases [9]. MMPs are connected with cancer cells survival, expansion, and they are synthetized by cancer cell in small amount. Cancer cells stimulate surrounding host cells to produce required MMPs. MMPs secreted by normal cells can bound to cancer cell surface and used by them [10].

\section{MMPs influence on tumor growth}

Several different mechanisms by which MMPs regulate the growth of cancer cells including release of cell membrane bound growth factors, modulation of bioavailability of growth factors, and indirect regulation of proliferative signals by integrins. MMPs may also inhibit tumor growth through TGF$b$ activation and/or stimulation of pro-apoptotic molecules production [11].

The degradation of ECM by different MMP members not only removes the physical barriers for growing tumor, but also releases a biologically active molecules, and reveals the hidden sites in the ECM. Especially the invasive cancer cell can find the actinrich protrusions of the plasma membrane associated with ECM degradation, called invadopodia. Soluble MMPs attach to adhesive molecules such as integ- rins located on the surface of invadopodia. MMPs degrade different ECM ingredients, releasing various types of molecules affecting cells behavior [12]. One of the major factors connected with tumor growth is $\mathrm{TGFb}$. Which is released after fibronectin degradation by MMP-9. In normal epithelial, and cancer cells at an early stage of tumor growth, TGF-b causes an inhibition of cell proliferation. It was observed, that $85 \%$ of all human cancers become resistant to the TGF-b inhibitory effect on proliferation [13]. Many growth factors are connected to the cell surface in inactive form, and the MMPs are responsible for growth factors activation. MMPs release TNF-a, one of the most important pro-inflammatory cytokines that is expressed as a membrane bound precursor (pro-TNFa) on the macrophages, and T-cell surface. TNF-a promotes the survival of tumor cells [14]. MMPs interact with integrin, and cadherins (cell adhesion molecules), which belongs to cell surface receptors group present on the surface of the neighboring cells or in ECM. Receptors on cell surfaces belong to a five major classes: integrin, cadherin, immunoglobulin (Ig-CAMs) family, selectins, and CD44 receptors. Tumor cells have an increased number of CD44 isoforms. CD44 receptors bind to MMP-9, and the resulting complex involved in the type IV collagen degradation. Activation of MMP-9 with CD44 produces changes in tumor angiogenesis, and invasiveness. In contrast, MT1-MMP is involved in the degradation of CD44, and promotion of cell migration [15].

\section{MMPs influence on apoptosis}

MMPs lead to apoptosis by cleaving adhesion molecules. MMP-3 induces apoptosis in case of its over-expression in epithelial cells [16]. 


\section{MMPs influence on angiogenesis}

Angiogenesis is a process of development of new blood vessels from the existing blood vessels. MMP2, MMP9, and MMP14 may stimulate or inhibit the angiogenesis process [17]. MMPs promote angiogenesis in basement membrane, and ECM components degradation. The basement membrane disruption allows the migration of endothelial cells from existing vessels to the newly created. MMPs stimulates angiogenesis through VEGF (vascular endothelial growth factor). VEGF is mitogen factor specific for endothelial cells, that stimulates formation of new blood vessels from preexisting blood vessels [1]. On the other hand, MMPs can also inhibit the process of angiogenesis by releasing angiostatin caused by plasminogen cleavage, and by endostatin production caused by collagen cleaving. Especially MMP-2, MMP-7, MMP-9, and MMP12 are capable of plasminogen digestion, and angiostatin releasing. However, endostatin, which is produced under the influence of MMP-3, MMP-7, MMP-9, MMP-12, MMP-13, and MMP-20, creates stable complexes with pro-MMP-9 and MMP-13, and blocs their activation [18]. The major role in angiogenesis played by MMP-2, MMP-9, and MT1MMP [19].

\section{MMPs role in invasion and metastasis}

The process of metastasis is a multistage mechanism, starting from losing the intercellular connections, ECM degradation, and releasing of single cells of the tumor through anoikis prevention, cell migration, penetration into the blood or lymphatic, adhesion to endothelial cells, and finally a secondary growth in the new location [20]. Anoikis is an epithelial to mesenchymal transition (EMT). In this process, epithelial cells change their phenotype from epithelial to mesenchymal with loss of their integrity. One of the main inducers of EMT is TGF-b, which is activated by MMPs. The cells of mesenchymal phenotype produce more MMPs which increasing their ability to metastasize. After moving to the metastatic locations, cancer cells can return to their original epithelial phenotype [21]. Two ways for cancer cell migration were described: moving of single cell or moving as a group of cells. During group of cell movement, cells connections are preserved, however when cells migrate individually, they move in a way that's called "mesenchymal" or "amoeboidal". Mesenchymal type of migration occurs after phenotype change form epithelial to mesenchymal cells. MMP involved in this pro- cess, and limited to connecting, and disconnecting phases of mesenchymal type of migration. During single cells migration, MMPs are involved with adhesion molecules on the cell surface. MMPs digest the ECM components, and therefore facilitate the movement of cells [1].

\section{MMPs inhibition strategies as an anticancer} target

MMPs play an important role in all stages of tumor progression including migration of tumor cells, escape from apoptosis, and immune surveillance, metastasis, and angiogenesis. The drugs with better antitumor activity should had specific inhibitors to MMPs members which has the pro-cancerogenic properties. The MMPs play a major role in the early stages of tumor growth suppression, and it could lead to tumor growth inhibition, and degradation. In contrast, in the fully formed, and vascularized tumor, the MMP activity is not critical. This may explain the lack of good results of therapy using MMPI, in advanced stages of cancer. The effect of MMP varies depending on the tumor type and/or stage of tumor [22]. The obvious relation between MMPs activity, and cancer development suggests the possibility of blocking of MMPs enzymatic activity. There are three main strategies of MMPs inhibition: at the level of transcription, activation, and inhibition.

At the transcription level, the MMPs inhibition can be achieved by extracellular factors (MMPs transcription can be inhibited by interferon), and by blocking transduction pathways. The next important issue in MMPs activity regulation is their activation because they are secreted as inactive enzyme form (pro-MMPs). This explains the role of anti-MMPs monoclonal antibodies as an effective MMP inhibitors. Active MMPs can be inhibited by exogenous, and endogenous factors, such as specific TIMMP or nonspecific $\alpha-2$ macroglobulin [23]. The MMPI can be divided into synthetic, and natural inhibitors. Selected synthetic inhibitors are in clinical trials in human (synthetic peptides, non-peptidic molecules, chemically modified tetracyclines, and bisphosphonates). Peptidomimetic MMPI are pseudopeptide derivative, act as a competitive inhibitor that inhibit MMPs activity mainly by interacting with $\mathrm{Zn}^{2+}$ ions in catalytic sites of MMPs.

Hydroxypyrones are alternative zinc binding groups (ZBGs) that combine with peptidomimetic forming a novel class of MMPI (Batimastat (BB94), Marimastat (BB-2516), Prinomastat (AG3340), and Tanomastat (BAY12- 9566). The other 
category of MMPI include the chemically modified tetracycylins (Metastat (COL-3, CMT-3), Minocycline, and Doxycycline). It inhibits MMPs by binding to zinc ions, and it entered phase II trials for Kaposi's sarcoma. Doxycycline is currently the only FDA officially approved MMPI for the prevention of Periodontitis [24].

Bisphosphonates besides their inhibition of the osteoclast activity, and bone resorption, it also inhibit selected MMPs activity. Bisphosphonates influence the protein expression of several MMPs, and TIMPs in breast cancer. Letrozole which is a nonsteroidal aromatase inhibitor, inhibits the gelatinases (MMP-2 and -9) released by breast cancer cells, and limits metastatic potential [25].

Genistein (soy isoflavonoid) is a natural substance with anticancer properties, it interferes with the expression of several MMPs, and TIMPs [26].

\section{Relationship of MMPs with ovarian cancer}

MMP-1 is the commonest expressed enzyme among the members of MMPs family. It is widely found in mesenchymal, epithelial, and endothelial cells. Overexpression of MMP-1 has been implicated in various malignant tumors and linked to early metastasis, and poor prognosis. The association of MMP-1 with the invasion of tumor cells involves the $\mathrm{G}$ protein-coupled receptor, proteaseactivated receptor-1 (PAR1). Agarwal et al, found that MMP-1 activates PAR1, which is an important signal transducer in angiogenesis in peritoneal mouse model of ovarian cancer. The activation of MMP1-PAR1 induces the secretion of angiogenic factors of interleukin- 8 from the ovarian carcinoma cells, which act on endothelial receptors, leading to endothelial cell proliferation, and migration. Therefore, MMP1-PAR1 pathways have been suggested as new targets for ovarian cancer therapy [27]. Wang et al, found increased expression of MMP-1 is closely correlated with the increased invasion of epithelial ovarian cancers. It was suggested that MMP1-PAR1 axis may be a future target for inhibition of metastasis in ovarian cancers. MMP-1 expression in ovarian cancer cell lines also requires other regulators as mixed lineage kinase 3 (MLK3) [28]. MMP-2 is $72 \mathrm{kDa}$. MMP-2 degrades type IV collagen (the primary component of basement membrane and ECM). The invasion and metastasis of tumors depend on the degradation of ECM, expression of MMP-2 plays a positive role in the progression of ovarian cancer. Overexpression of MMP-2 in peritoneal implants of ovarian cancers is related to risk of death [29].
The expression of MMP-2 in serous and mucinous ovarian cancers is significantly higher compared with benign and borderline ovarian tumor [30]. Huang and Sui showed that the positive rate of MMP-2, vascular endothelial growth factor $\mathrm{C}$ (VEGF-C) and E-cadherin was higher in ovarian cancers than in benign and borderline ovarian tumors [31]. MMP-2 level is positively correlated with clinical stage and metastasis of ovarian cancers, but not with pathologic grading [32]. MMP-2 expression predicts a lower overall survival rate, and MMP-2 is considered a prognostic factor for ovarian cancer [33]. Several studies attempted to evaluate the role of MMP-2 as a therapeutic target for ovarian cancer. Wang et al, showed that epigallocatechin3 -gallate inhibits the proliferation and migration of ovarian cancer cells by down-regulation of MMP-2 expression [34]. Zoledronic acid exerts robust inhibitory activity on ovarian cancer cells invasion through decreasing the intracellular level of MMP2 [35]. MMP-7 is the smallest member in MMPs family. MMP-7 overexpression was detected in cancer cells and it plays a critical role in both early and later stages of tumors [36]. Wang et al, showed that overexpression of MMP-7 in EOC is stimulated by VEGF and IL-8 [37]. Moreover, MMP-7 promotes the metastasis of ovarian cancer cells by activating gelatin enzyme. MMP-7 also promotes the metastasis of ovarian cancer through mesothelin (MSLN) pathways [38]. Therefore, blocking the MSLN-related pathway might be a therapeutic measure for the inhibition of ovarian cancer progression. Zhao et al, showed that triptolide inhibits the invasion of ovarian cancer cells through suppressing the expression of MMP-7 in vitro, and concluded that triptolide can be used as a candidate for treatment of ovarian cancer [39]. Increased metabolites of 5-lipoxygenase from hypoxic ovarian cancer cells can facilitate the invasion of macrophages, which is achieved via overexpression of MMP-7 through p38 pathway [40]. MMP-9 has $92 \mathrm{kDa}$ molecular mass and belongs to the type IV gelatin. MMP-9 capable of basement membrane type IV collagen degradation, which plays an essential role in the malignant tumor invasion and metastasis. Wang et al, demonstrated that platelet-derived growth factor-D promotes the ovarian cancer invasion and metastasis through upregulating the expression of MMP-9 [41]. Hu et al, found that MMP-9 level in ovarian cancer is higher compared with normal ovarian tissues and benign ovarian tumors. Furthermore, the postoperative levels of MMP-9 in ovarian cancer are significantly reduced compared with preoperative levels [42]. Consequently, MMP-9 was suggested as a potential se- 
rum marker for the diagnosis of ovarian cancer, and high serum MMP-9 level might be a predictor for refractory tumors. MMP-9 expression is positively correlated with FIGO staging, and lymph node metastasis in ovarian cancer, suggesting that increased MMP9 expression is associated with poor prognosis of ovarian cancer [43]. MMP-9 was suggested as a therapeutic target for ovarian cancer therapy. It has been shown that filamin B can suppress the ovarian cancer metastasis by down-regulation of MMP-9, and secretion of VEGF-A [44].

Bisdemethoxycurcumin can inhibit ovarian cancer growth through inhibition of MMP-2 and -9 expression [45]. MMP-8 can promote the ovarian cancer metastasis via up-regulation of IL-1b [46]. MMP-14 (membrane-type 1 MMP (MT1-MMP)) plays an important role in cancers invasion and metastasis through activation of proMMP-2, and ECM degradation [47].

MMP-14 overexpression was associated with low progression rate, and better prognosis of ovarian cancers [48]. Moreover, patients with double expression of MMP-14 and CD44 have a poor prognosis [49]. Kaimal et al, showed that a monoclonal antibody, which selectively blocks MMP-14, can restrain the growth, and angiogenesis of ovarian cancer [50]. Human leukocyte antigen G-G was associated with the tumor invasion and metastasis through mediating MMP-15 overexpression in ovarian cancers [51].

\section{Future Considerations}

Cancer is a leading cause of death worldwide, and therefore the research on the new agents with potential anticancer properties are important. MMPs play crucial role in ECM remodeling, and cancer progression, so MMPS and MMPI could be a target for newly synthetized anticancer drugs.

The link of MMPs with the apoptosis, cell migration, and angiogenesis, allows the use of MMPs as tumor markers. An increased expression of MMPs in both tissues, and blood of patients with various cancers observed. MMPs have potential value as marker of invasiveness, and distant metastasis. There are few studies examining the concentration of MMPs in vivo, but the possibility of MMPs inhibition by synthetic inhibitors could offer the hope to implement new therapeutic strategies for treating cancer patients.

\section{References}

1 Jabłońska-Trypuć A, Matejczyk M, Rosochacki S. Matrix metalloproteinases (MMPs), the main extracellular matrix (ECM) enzymes in collagen degradation, as a target for anticancer drugs. J Enzyme Inhib Med Chem. 2016;31(sup1):177-183. doi: 10.3109/14756366.2016.1161620. [PubMed]

2 Fink K, Boratyński J. Rola metaloproteinaz w modyfikacji macierzy zewnątrzkomórkowej w nowotworowym wzroście inwazyjnym, w przerzutowaniu i w angiogenezie [The role of metalloproteinases in modification of extracellular matrix in invasive tumor growth, metastasis and angiogenesis]. Postepy Hig Med Dosw (Online). 2012; 66:609-28. Polish. doi: 10.5604/17322693.1009705. [PubMed]

3 Heino J. The collagen family members as cell adhesion proteins. Bioessays. 2007;29(10):1001-10. doi: 10.1002/bies.20636. [PubMed]

4 Myllyharju J, Kivirikko KI. Collagens, modifying enzymes and their mutations in humans, flies and worms. Trends Genet. 2004;20(1):33-43. doi: 10.1016/j.tig.2003.11.004. [PubMed]

5 Nagase H, Visse R, Murphy G. Structure and function of matrix metalloproteinases and TIMPs. Cardiovasc Res. 2006;69(3):562-73. doi: 10.1016/j.cardiores.2005.12.002. [PubMed]

6 Bogaczewicz J, Sysa-Jedrzejowska A, Woźniacka A. Rola metaloproteinaz macierzy w pierwotnych ukladowych zapaleniach naczyń [Role of matrix metalloproteinases in primary systemic vasculitis]. Pol Merkur Lekarski. 2008;24(140):85-9. Polish. [PubMed]

7 Hrabec E, Naduk J, Strek M, et al. Kolagenazy typu IV (MMP-2 i MMP-9) i ich substraty--białka macierzy zewnatrzkomórkowej, hormony, cytokiny, chemokiny i ich receptory [Type IV collagenases (MMP-2 and MMP-9) and their substrates--intracellular proteins, hormones, cytokines, chemokines and their receptors]. Postepy Biochem. 2007;53(1):37-45. Polish. [PubMed]

8 Yadav L, Puri N, Rastogi V, et al. Matrix metalloproteinases and cancer - roles in threat and therapy. Asian Pac J Cancer Prev. 2014;15(3):1085-91. doi: 10.7314/apjcp.2014.15.3.1085. [PubMed]

9 Mannello F, Tonti G, Papa S. Matrix metalloproteinase inhibitors as anticancer therapeutics. Curr Cancer Drug Targets. 2005;5(4):285-98. doi: 10.2174/1568009054064615. [PubMed]

10 Noël A, Jost M, Maquoi E. Matrix metalloproteinases at cancer tumor-host interface. Semin Cell Dev Biol. 2008;19(1):5260. doi: 10.1016/j.semcdb.2007.05.011. [PubMed]

11 Egeblad M, Werb Z. New functions for the matrix metalloproteinases in cancer progression. Nat Rev Cancer. 2002;2(3):16174. doi: 10.1038/nrc745. [PubMed]

12 Rozanov DV, Hahn-Dantona E, Strickland DK, et al. The low-density lipoprotein receptor-related protein LRP is regulated by membrane type-1 matrix metalloproteinase (MT1-MMP) proteolysis in malignant cells. J Biol Chem. 2004: 279(6):4260-8. doi: 10.1074/jbc.M311569200. [PubMed]

13 Krzyzanowska-Gołab D, Lemańska-Perek A, Katnik-Prastowska I. et al. Fibronectin as an active component of the extracellular matrix]. Postepy Hig Med Dosw (Online). 2007; 61:655-63. Polish. [PubMed] 
14 Ungefroren H, Sebens S, Seidl D, et al. Interaction of tumor cells with the microenvironment. Cell Commun Signal. 2011; 9:18. doi: 10.1186/1478-811X-9-18. [PubMed]

15 Bourboulia D, Stetler-Stevenson WG. Matrix metalloproteinases (MMPs) and tissue inhibitors of metalloproteinases (TIMPs): Positive and negative regulators in tumor cell adhesion. Semin Cancer Biol. 2010;20(3):161-8. doi: 10.1016/j.semcancer.2010.05.002. [PubMed]

16 Paoli P, Giannoni E, Chiarugi P. Anoikis molecular pathways and its role in cancer progression. Biochim Biophys Acta. 2013;1833(12):3481-3498. doi: 10.1016/j.bbamcr.2013.06.026. [PubMed]

17 Rundhaug JE. Matrix metalloproteinases, angiogenesis, and cancer: commentary re: A. C. Lockhart et al., Reduction of wound angiogenesis in patients treated with BMS-275291, a broad spectrum matrix metalloproteinase inhibitor. Clin. Cancer Res., 9: 00-00, 2003. Clin Cancer Res. 2003;9(2):551-4. [PubMed]

18 Deryugina EI, Quigley JP. Pleiotropic roles of matrix metalloproteinases in tumor angiogenesis: contrasting, overlapping and compensatory functions. Biochim Biophys Acta. 2010;1803(1):103-20. doi: 10.1016/j.bbamcr.2009.09.017. [PubMed]

19 López-Otín C, Overall CM. Protease degradomics: a new challenge for proteomics. Nat Rev Mol Cell Biol. 2002;3(7):50919. doi: 10.1038/nrm858. [PubMed]

20 Yoon SO, Park SJ, Yun CH, et al. Roles of matrix metalloproteinases in tumor metastasis and angiogenesis. J Biochem Mol Biol. 2003;36(1):128-37. doi: 10.5483/bmbrep.2003.36.1.128. [PubMed]

21 Illman SA, Lehti K, Keski-Oja J, et al. Epilysin (MMP-28) induces TGF-beta mediated epithelial to mesenchymal transition in lung carcinoma cells. J Cell Sci. 2006;119(Pt 18):3856-65. doi: 10.1242/jcs.03157. [PubMed]

22 Vihinen P, Ala-aho R, Kähäri VM. Matrix metalloproteinases as therapeutic targets in cancer. Curr Cancer Drug Targets. 2005;5(3):203-20. doi: 10.2174/1568009053765799. [PubMed]

23 Vihinen P, Kähäri VM. Matrix metalloproteinases in cancer: prognostic markers and therapeutic targets. Int J Cancer. 2002;99(2):157-66. doi: 10.1002/ijc.10329. [PubMed]

24 Sapadin AN, Fleischmajer R. Tetracyclines: nonantibiotic properties and their clinical implications. J Am Acad Dermatol. 2006;54(2):258-65. doi: 10.1016/j.jaad.2005.10.004. [PubMed]

25 Coxon FP, Thompson K, Rogers MJ. Recent advances in understanding the mechanism of action of bisphosphonates. Curr Opin Pharmacol. 2006;6(3):307-12. doi: 10.1016/j.coph.2006.03.005. [PubMed]

26 Huang X, Chen S, Xu L, et al. Genistein inhibits p38 map kinase activation, matrix metalloproteinase type 2, and cell invasion in human prostate epithelial cells. Cancer Res. 2005;65(8):3470-8. doi: 10.1158/0008-5472.CAN-04-2807. [PubMed]

27 Agarwal A, Tressel SL, Kaimal R, et al. Identification of a metalloprotease-chemokine signaling system in the ovarian cancer microenvironment: implications for antiangiogenic therapy. Cancer Res. 2010;70(14):5880-90. doi: 10.1158/0008-5472. CAN-09-4341. [PubMed]

28 Wang FQ, Fisher J, Fishman DA. MMP-1-PAR1 axis mediates LPA-induced epithelial ovarian cancer (EOC) invasion. Gynecol Oncol. 2011;120(2):247-55. doi: 10.1016/j.ygyno.2010.10.032. [PubMed]

29 Périgny M, Bairati I, Harvey I, et al. Role of immunohistochemical overexpression of matrix metalloproteinases MMP-2 and MMP-11 in the prognosis of death by ovarian cancer. Am J Clin Pathol. 2008;129(2):226-31. doi: 10.1309/49LA9XCBGWJ8F2KM. [PubMed]

30 Furuya M, Ishikura H, Kawarada $\mathrm{Y}$, et al. Expression of matrix metalloproteinases and related tissue inhibitors in the cyst fluids of ovarian mucinous neoplasms. Gynecol Oncol. 2000;78(2):106-12. doi: 10.1006/gyno.2000.5856. [PubMed]

31 Huang KJ, Sui LH. The relevance and role of vascular endothelial growth factor C, matrix metalloproteinase-2 and Ecadherin in epithelial ovarian cancer. Med Oncol. 2012;29(1):318-23. doi: 10.1007/s12032-010-9817-4. [PubMed]

32 Wang L, Jin X, Lin D, et al. Clinicopathologic significance of claudin-6, occludin, and matrix metalloproteinases -2 expression in ovarian carcinoma. Diagn Pathol. 2013; 8:190. doi: 10.1186/1746-1596-8-190. [PubMed]

$33 \mathrm{Fu} \mathrm{Z}, \mathrm{Xu} \mathrm{S}, \mathrm{Xu} \mathrm{Y}$, et al. The expression of tumor-derived and stromal-derived matrix metalloproteinase 2 predicted prognosis of ovarian cancer. Int J Gynecol Cancer. 2015; 25(3):356-62. doi: 10.1097/IGC.0000000000000386. [PubMed]

34 Wang F, Chang Z, Fan Q, Wang L. Epigallocatechin-3-gallate inhibits the proliferation and migration of human ovarian carcinoma cells by modulating p38 kinase and matrix metalloproteinase-2. Mol Med Rep. 2014;9(3):1085-9. doi: 10.3892/ mmr.2014.1909. [PubMed]

35 Gonzalez-Villasana V, Fuentes-Mattei E, Ivan C, et al. Rac1/Pak1/p38/MMP-2 Axis Regulates Angiogenesis in Ovarian Cancer. Clin Cancer Res. 2015; 21(9):2127-37. doi: 10.1158/1078-0432.CCR-14-2279. [PubMed]

36 Zohny SF, Fayed ST. Clinical utility of circulating matrix metalloproteinase-7 (MMP-7), CC chemokine ligand 18 (CCL18) and CC chemokine ligand 11 (CCL11) as markers for diagnosis of epithelial ovarian cancer. Med Oncol. 2010; 27(4):1246-53. doi: 10.1007/s12032-009-9366-x. [PubMed]

37 Wang FQ, So J, Reierstad S, Fishman DA. Matrilysin (MMP-7) promotes invasion of ovarian cancer cells by activation of progelatinase. Int J Cancer. 2005; 114 (1):19-31. doi: 10.1002/ijc.20697. [PubMed]

38 Chang MC, Chen CA, Chen PJ, et al. Mesothelin enhances invasion of ovarian cancer by inducing MMP-7 through MAPK/ERK and JNK pathways. Biochem J. 2012; 442(2):293-302. doi: 10.1042/BJ20110282. [PubMed]

39 Zhao H, Yang Z, Wang X, et al. Triptolide inhibits ovarian cancer cell invasion by repression of matrix metalloproteinase 7 and 19 and upregulation of E-cadherin. Exp Mol Med. 2012;44(11):633-41. doi: 10.3858/emm.2012.44.11.072. [PubMed]

40 Wen Z, Liu H, Li M, et al. Increased metabolites of 5-lipoxygenase from hypoxic ovarian cancer cells promote tumorassociated macrophage infiltration. Oncogene. 2015; 34(10):1241-52. doi: 10.1038/onc.2014.85. [PubMed]

41 Wang Y, Hu C, Dong R, et al. Platelet-derived growth factor-D promotes ovarian cancer invasion by regulating matrix metalloproteinases 2 and 9. Asian Pac J Cancer Prev. 2011;12(12):3367-70. [PubMed]

$42 \mathrm{Hu} \mathrm{X}$, Li D, Zhang W, et al. Matrix metalloproteinase-9 expression correlates with prognosis and involved in ovarian cancer cell invasion. Arch Gynecol Obstet. 2012; 286 (6):1537-43. doi: 10.1007/s00404-012-2456-6. [PubMed]

$43 \mathrm{Li} \mathrm{LN}$, Zhou X, Gu Y, et al. Prognostic value of MMP-9 in ovarian cancer: a meta-analysis. Asian Pac J Cancer Prev. 2013; 14 (7):4107-13. doi: 10.7314/apjcp.2013.14.7.4107. [PubMed] 
44 Bandaru S, Zhou AX, Rouhi P, et al. Targeting filamin B induces tumor growth and metastasis via enhanced activity of matrix metalloproteinase-9 and secretion of VEGF-A. Oncogenesis. 2014; 3(9): e119. doi: 10.1038/oncsis.2014.33. [PubMed]

45 Pei H, Yang Y, Cui L, et al. Bisdemethoxycurcumin inhibits ovarian cancer via reducing oxidative stress mediated MMPs expressions. Sci Rep. 2016; 6: 28773. doi: 10.1038/srep28773. [PubMed]

46 Stadlmann S, Pollheimer J, Moser PL, et al. Cytokine-regulated expression of collagenase-2 (MMP-8) is involved in the progression of ovarian cancer. Eur J Cancer. 2003; 39 (17):2499-505. doi: 10.1016/j.ejca.2003.08.011. [PubMed]

47 Shiomi T, Okada Y. MT1-MMP and MMP-7 in invasion and metastasis of human cancers. Cancer Metastasis Rev. 2003; 22 (2-3):145-52. doi: 10.1023/a:1023039230052. [PubMed]

48 Trudel D, Desmeules P, Turcotte S, et al. Visual and automated assessment of matrix metalloproteinase-14 tissue expression for the evaluation of ovarian cancer prognosis. Mod Pathol. 2014;27(10):1394-404. doi: 10.1038/modpathol.2014.32. [PubMed]

49 Vos MC, Hollemans E, Ezendam N, et al. MMP-14 and CD44 in Epithelial-to-Mesenchymal Transition (EMT) in ovarian cancer. J Ovarian Res. 2016; 9(1):53. doi: 10.1186/s13048-016-0262-7. [PubMed]

50 Kaimal R, Aljumaily R, Tressel SL, et al. Selective blockade of matrix metalloprotease-14 with a monoclonal antibody abrogates invasion, angiogenesis, and tumor growth in ovarian cancer. Cancer Res. 2013;73(8):2457-2467. doi: 10.1158/0008-5472. CAN-12-1426. [PubMed]

51 Lin A, Xu HH, Xu DP, et al. Multiple steps of HLA-G in ovarian carcinoma metastasis: alter NK cytotoxicity and induce matrix metalloproteinase-15 (MMP-15) expression. Hum Immunol. 2013;74(4):439-46. doi: 10.1016/j.humimm.2012.11.021. [PubMed] 